\title{
Peripheral Ameloblastoma In An Adolescent Male Mimicking Pyogenic Granuloma: An Unusual Finding
}

\author{
Authors \\ Nishat Afroz ${ }^{1}$, Divya Rabindranath ${ }^{2}$, Nida Shamim ${ }^{3}$, Azka Anees Khan ${ }^{4}$, Senthil.P ${ }^{5}$, \\ Aaliya Ehsan ${ }^{6}$ \\ ${ }^{1}$ Associate Professor, Department of Pathology,J.N.Medical College, Aligarh \\ Email: nishat_ehsaan@yahoo.com \\ ${ }^{2}$ Junior Resident, Department of Pathology,J.N.Medical College, Aligarh \\ Email:divy30@hotmail.com \\ ${ }^{3}$ Junior Resident, Department of Pathology,J.N.Medical College, Aligarh \\ Email: nidasham75@gmail.com \\ ${ }^{4}$ Junior Resident, Department of Pathology, J.N.Medical College, Aligarh \\ Email:azka.asquare.anees@gmail.com \\ ${ }^{5}$ Junior Resident, Department of Pathology, J.N.Medical College, Aligarh \\ Email: senthiljune07@gmail.com \\ ${ }^{6}$ Junior Resident, Department of Pathology, J.N.Medical College, Aligarh. \\ Email: ehsanaaliya10@gmail.com \\ Corresponding Author \\ Dr. Divya Rabindranath \\ 24D, Vinayagar koil street, Nalvar layout, Rathinapuri, Coimbatore-641027, Tamilnadu, India. \\ Email:divy30@hotmail.com,Ph:07895683197.
}

\begin{abstract}
:
Peripheral ameloblastoma (PA) is a benign, uncommon extraosseous odontogenic soft tissue tumour. Though it has same histological features as that of classical intraosseous ameloblastoma, it is unique in that it has an extraosseous location confined to the gingiva or alveolar mucosa. The authors here report a case report of PA in a 26 year old male with clinical diagnosis of pyogenic granuloma, thereby highlighting the importance of histological examination for the diagnosis of this tumour and also to have a suspicion of PA in the differential diagnosis of nodular lesions of the gingiva and alveolar mucosa
\end{abstract}

\section{Introduction}

Prevalence of odontogenic tumor is $0.8 \%$ of all oral and maxillofacial pathology with Ameloblastoma accounting for $30 \%$ of these. ${ }^{[1]}$ The peripheral ameloblastoma (PA) is an exophytic growth localized to the soft tissues overlying the tooth-bearing areas of the jaws, the initial diagnosis often being fibrous epulis. Most of the times there is no radiological evidence of bone involvement, but during surgery it may reveal superficial bone erosion known as cupping or saucerization. PA occurs at a significantly higher age (52.1years) than the intraosseous ameloblastoma (IA-37.4 years). There is higher male preponderance of PA as compared to IA with $32.6 \%$ cases involving the mandibular 


\section{JMSCR Vol.||03||Issue||08||Page 6983-6986||August}

premolar region ${ }^{[2]}$. Here, we are reporting a case of peripheral ameloblastoma in a 26 year old male, clinically diagnosed as pyogenic granuloma.

\section{Case report}

A 26-year-old male patient presented to the periodontology OPD of our hospital with a painless swelling on the gingiva. The patient could not tell us as to when he noted the lesion. The intra-oral examination revealed a nodule which was covered by erythematous mucosa, with an irregular surface and a firm consistency, which was located in the left posterior alveolar mucosa, measuring approximately $5 \times 4 \times 3 \mathrm{~mm}$ (Fig A) The periapical radiograph examination displayed no bone erosion (Fig B). A provisional diagnosis of pyogenic granuloma was made and an excision was performed. The specimen was fixed in $10 \%$ formalin buffer and it was sent for histopathological examination.

The microscopical finding was nests of odontogenic epithelial cells showing ameloblastlike peripheral cells with polarized nuclei and central cells stellate reticulum like features. These nests were distributed in the fibrous stroma and they seemed to fuse with the keratinized stratified squamous epithelium that covered the lesion (Fig C, D). The histological surgical margin of the excised lesion was disease-free. The diagnosis was peripheral ameloblastoma. The patient is in follow-up for six months without any signs of recurrence.

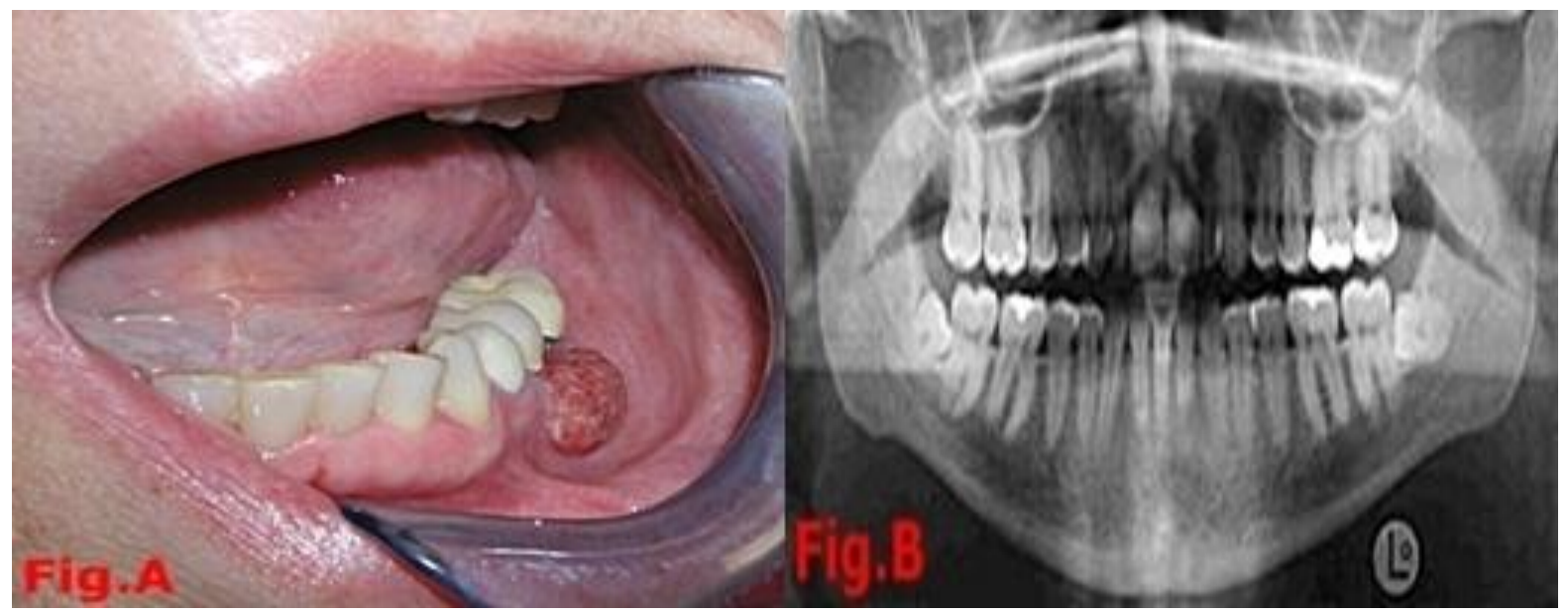

Fig.A: Nodular exophytic growth in the left vestibular alveolar mucosa.

Fig.B: OPG showing no bony erosion.

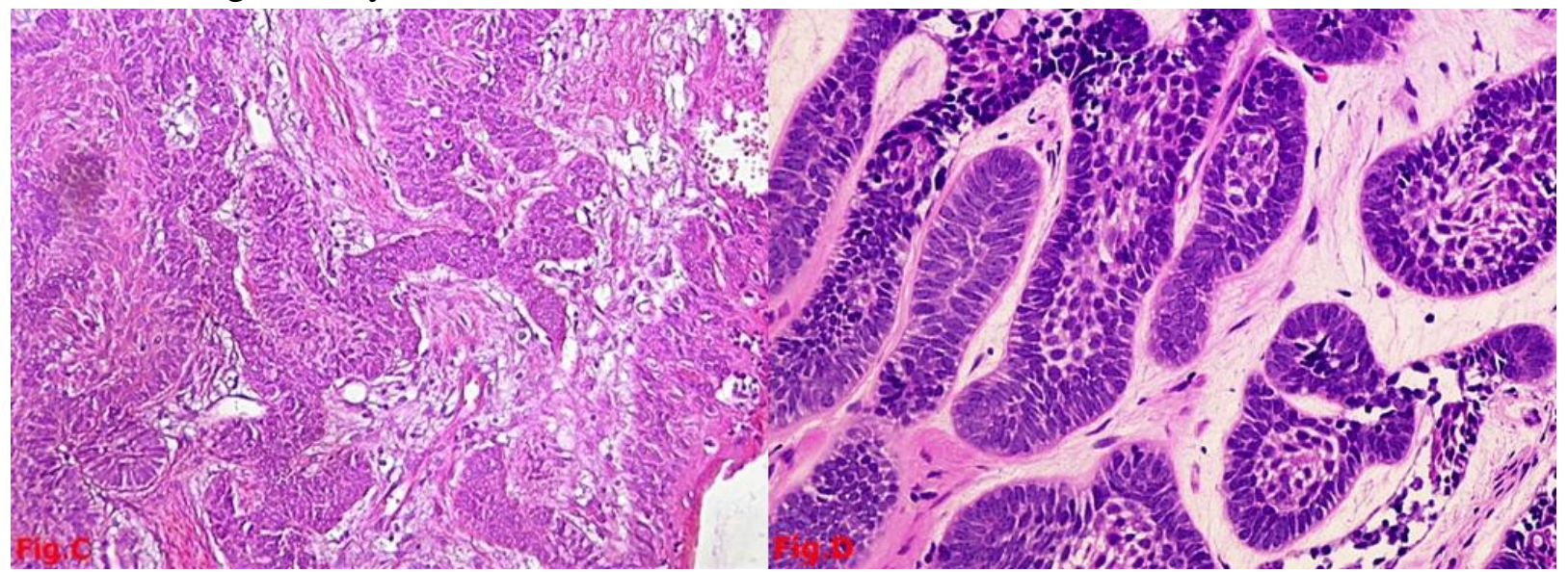

Fig.C: Nests of odontogenic epithelial cells fuse with the overlying keratinized squamous epithelium (H\&EX 10x)

Fig.D: Nests of odontogenic epithelial cells showing ameloblast-like peripheral cells with polarized nuclei and central cells stellate reticulum like features (H\&EX 40x) 


\section{Discussion}

According to Buchner and Sciubba, PA is defined as a tumor with the histologic characteristics of an intraosseous ameloblastoma but occurring in the soft tissue overlying the tooth-bearing regions of the maxilla and mandible. ${ }^{[3,4]}$ According to WHO classification (2005), "the extraosseous/PA is the extraosseous counterpart of the intraosseous solid/multicystic ameloblastoma". ${ }^{[5]}$ A review of the English literature disclosed 70 well documented cases of PA till 2005. ${ }^{[6]}$ Since, then very few cases have been reported. ${ }^{[7-10]}$

The overall average age is 52.1 years, slightly higher for males (52.9 years) than for females (50.6 years). Thus, the PA occurs at a significantly higher age than the intraosseous ameloblastoma (IA-37.4 years). ${ }^{[2]}$ Our patient presented at a much younger age of 12 years.

PA is a painless, sessile, firm and exophytic growth with relatively smooth sometimes granular, pebbly, papillary or warty surface. ${ }^{[2,11]}$ The color of the lesion varies between normal or pink and red or dark red. ${ }^{[2]}$ In a study by Mintz et al, the tumors ranged between 0.2 and $4.0 \mathrm{~cm}$ in diameter, with a mean of $1.4 \mathrm{~cm} .{ }^{[12]}$ Most of the times there is no radiological evidence of bone involvement, but during surgery it may reveal a superficial bone erosion known as cupping or saucerization. ${ }^{[2]}$ Mandible has been clearly the most common site of occurrence for $\mathrm{PA}^{[2,12]}$ with the mandibular premolar region to be the most common site of involvement. ${ }^{[12,13]}$

The gross specimen consists of a firm to slightly spongy mass of pink to pinkish grey color. The cut surface may contain minute cystic spaces filled with clear, pale yellow fluid. ${ }^{[2]}$ Histologically, the tissue is composed of islands and strands of odontogenic epithelium, usually resembling the follicular pattern of intraosseous ameloblastoma. Most of the islands exhibit palisading of columnar basal cells and a stellate reticulum is seldom conspicuous ${ }^{[2,}{ }^{14]}$ The epithelial islands commonly exhibit the acanthomatous variant of this pattern, with central areas of keratin formation, or the cystic pattern.
Immunohistochemically, PA showed positive reactivity for AE1/AE3, KL1,34, E12, and MNF116 cytokeratin and negative staining for CK8, CK10, CK13, CK17, and CK18, are in accordance with the observation seen in human enamel organ ${ }^{\text {[15] }}$

PA should be differentiated from peripheral reactive lesions such as pyogenic granuloma, epulis, papilloma, fibroma, peripheral giant-cell granuloma, peripheral odontogenic fibroma, peripheral-ossifying fibroma, Baden's odontogenic gingival epithelial hamartoma, and basal cell carcinoma ${ }^{\text {[2]. }}$

The current treatment of choice is conservative supra periosteal surgical excision with adequate disease-free margins ${ }^{[2]}$. Continuous followup is necessary as late recurrence is also reported. In our case, complete surgical excision was done, and patient is on continuous followup since last six months with no recurrence noted so far.

\section{References}

1. V. Jones and C. D. Franklin, "An analysis of oral and maxillofacial pathology found in adults over a 30-year period," Journal of Oral Pathology andMedicine, vol. 35, no. 7, pp. 392-401, 2006.

2. H. P. Philipsen, P. A. Reichart, H. Nikai, T. Takata, and Y.Kudo, "Peripheral ameloblastoma: biological profile based on 160 cases from the literature," Oral Oncology, vol. 37, no. 1, pp.17-27, 2001.

3. Woo SB, Smith-Williams JE, Sciubba JJ, Lipper S. Peripheral ameloblastoma of the buccal mucosa: case report and review of the English literature. Oral Surg Oral Med Oral Pathol 1987;63(1):78-84.

4. Zhu EX, Okada N, Takagi M. Peripheral ameloblastoma: case report and review of literature. J Oral Maxillofac Surg 1995;53(5):590-4.

5. WHO classification of tumors. Pathology and Genetics of Head and Neck Tumors Chapter 6.Odontogenic tumors; IARC: Lyon 2006:297-8. 
6. Shetty K. Peripheral ameloblastoma: an etiology from surface epithelium? Case report and review of literature. Oral Oncol Extra 2005;41(9):211-5.

7. Martelli-Júnior H, Souza LN, Santos LA, Melo-Filho MR, De Paula AM. Peripheral ameloblastoma: a case report. Oral Surg Oral Med Oral Pathol Oral Radiol Endod 2005;99(5):E31-3.

8. Lecorn DW, Bhattacharyya I, Vertucci FJ. Peripheral ameloblastoma: a case report and review of the literature. $\mathbf{J}$ Endod 2006;32(2):152-4.

9. Vanoven BJ, Parker NP, Petruzzelli GJ. Peripheral ameloblastoma of the maxilla: a case report and literature review. Am J Otolaryngol 2008;29(5):357-60.

10. Ide F, Mishima K, Miyazaki Y, Saito I, Kusama K. Peripheral ameloblastoma insitu: an evidential fact of surface epithelium origin. Oral Surg Oral Med Oral Pathol Oral Radiol Endod 2009;108(5):763-7.

11. Pekiner FN, Özbayrak S, Şener BC, Olgaç V, Sinanoğlu A. Peripheral ameloblastoma: a case report. Dentomaxillofac Radiol 2007;36(3):183-6.

12. Mintz S, Anavi Y, Sabes WR. Peripheral ameloblastoma of the gingiva. A case report. J Periodontol 1990;61(10):649-52.

13. Shiba R, Sakoda S, Yamada N. Peripheral ameloblastoma. J Oral Maxillofac Surg 1983;41(7):460-3.

14. Pekiner FN, Özbayrak S, Şener BC, Olgaç V, Sinanoğlu A. Peripheral ameloblastoma: a case report. Dentomaxillofac Radiol 2007;36(3):183-6.

15. A.R.Gould, A. G. Farman, E. K. DeJean, and L. R. Van Arsdall, "Peripheral ameloblastoma: an ultrastructural analysis," Journal of Oral Pathology, vol. 11, no. 2, pp. 90-101,1982. 